\title{
Morphological and clinical aspects of the occurrence of accessory (multiple) renal arteries
}

Ewelina Gulas ${ }^{1}$, Grzegorz Wysiadecki², Jacek Szymański², Agata Majos ${ }^{3}$, Ludomir Stefańczyk Mirosław Topol'2, Michał Polguj ${ }^{1}$

\author{
${ }^{1}$ Department of Angiology, Interfaculty Chair of Anatomy and Histology, \\ Medical University of Lodz, Lodz, Poland \\ ${ }^{2}$ Department of Normal and Clinical Anatomy, Interfaculty Chair of Anatomy \\ and Histology, Medical University of Lodz, Lodz, Poland \\ ${ }^{3}$ Department of Radiological and Isotopic Diagnosis and Therapy, Medical University \\ of Lodz, Lodz, Poland \\ ${ }^{4}$ Department of Radiology, Medical University of Lodz, Lodz, Poland
}

Submitted: 7 May 2015

Accepted: 16 August 2015

Arch Med Sci 2018; 14, 2: 442-453

DOI: $10.5114 /$ aoms.2015.55203

Copyright $\odot 2016$ Termedia \& Banach

\begin{abstract}
Renal vascularization variants vastly differ between individuals due to the very complex embryogenesis of the kidneys. Moreover, each variant may have implications for clinical and surgical interventions. The number of operating procedures continues to grow, and includes renal transplants, aneurysmorrhaphy and other vascular reconstructions. In any surgical technique, unawareness of the presence of multiple renal arteries may result in a fatal outcome, especially if laparoscopic methods are used. The aim of this review is to comprehensively identify the variation within multiple renal arteries and to highlight the connections between the presence of accessory renal arteries and the coexistence of other variants of vascularization. Another aim is to determine the potential clinical implications of the presence of accessory renal arteries. This study is of particular importance for surgeons, intervention radiologists, nephrologists and vascular surgeons.
\end{abstract}

Key words: kidney, renal artery, accessory, multiple, anatomical variation.

\section{Introduction}

In classic anatomic descriptions, typical renal vascularization is described as a single renal artery originating from the abdominal aorta at the level of the intervertebral disc between L1 and L2, just below the inception of the superior mesenteric artery. The renal artery enters the renal hilum, branches within the renal sinus and sends out interlobar arteries, which are situated between the renal pyramids in the cortex and take an arched course along the base of the pyramid, between the medulla and the cortex. Here, the interlobar arteries are designated arcuate arteries. Interlobular arteries branch from the arcuate arteries and ascend through the cortex towards the renal capsule. As they travel to the renal capsule, the interlobular arteries give off branches, the afferent arterioles, to each glomerulus.

In 2008, the simplest definition of accessory renal artery was introduced by Mir et al. [1]. While "normal" renal arteries were described as entering the kidney through its hilum, the accessory renal arteries might

\author{
Corresponding author: \\ Michat Polguj \\ Department of Angiology \\ Interfaculty Chair \\ of Anatomy and Histology \\ Medical University of Lodz \\ 60 Narutowicza St \\ 90-136 Lodz, Poland \\ Phone: +48 426304949 \\ E-mail: \\ michal.polguj@umed.lodz.pl
}


enter the renal artery through the hilum or through the surfaces of the kidney [1]. However, from the sixteenth century until today, accessory renal artery terminology has been controversial and unclear [2, 3]. The first description of accessory renal arteries was given in the sixteenth century. In 1564, Eustachi wrote about accessory renal arteries: "These arteries are end-arteries, they are not supplemental or accessory as they are frequently called in textbooks. They do not make anastomotic connections once they enter the kidney" [4].

This long held opinion, that there is usually only one renal artery vascularizing the kidney, has been rejected with a new thesis claiming that the most common type of renal vascularization contains accessory renal arteries, which are classified according to their origin, given by Merklin and Michels (1958) [5] as:

1) accessory renal arteries originating from the aorta,

2) accessory renal arteries originating from the main renal artery,

3) accessory renal arteries originating from other sources.

In 1956, Graves [6] considered that due to lack of standards, the term "multiple" could describe any additional vessel entering the kidney, either originating from the abdominal aorta or the main renal artery. In 1958, Merklin and Michels [5] used the designations main renal, aortic superior/inferior polar and renal inferior polar arteries. In 1962, Geyer and Poutasse [7] classified the additional vessels of the kidney as supernumerary, accessory or aberrant, and they also confirmed the sizes of these vessels to be different. In 1969, Poisel and Spängler [8] divided additional renal arteries according to the areas of kidney which they penetrate - accessory, supplementary and supernumerary renal arteries enter through the renal hilum, while aberrant renal arteries penetrate an area of the kidney other than its hilum.

In 1982, Stephens [9] claimed that as the vessels are not superfluous, but essential non-anastomotic arteries corresponding to the segmental branch of a single renal artery, the terms accessory, supernumerary or aberrant were not suitable for them. In 1992, Sampaio and Passos [10] introduced the terms hilar for the aortic branch penetrating the hilum, extrahilar for the branch of the renal artery with an extra-hilar penetration, superior polar for the aortic branch penetrating the superior pole and inferior polar for the aortic or common iliac artery penetrating the inferior pole of the kidney. They also claim that these vessels should be denominated as multiple, because they are segmental end-arteries.

In 2001, Satyapal et al. [2] denominated the artery arising from the abdominal aorta and ending in the kidney as additional. In the same year, Vilhova et al. [11] classified renal arteries originating from the aorta, or its major branches supplying the superior or inferior renal poles, on the basis of their point of entry to the renal parenchyma via the hilum as accessory or outside the hilum as perforated.

In 2004, Bordei et al. [12] introduced three new definitions: superior/inferior polar arteries which distribute blood to the renal poles, main renal artery as the largest hilar artery and hilar supplementary artery as the smaller one. In 2005, Holden et al. [13] defined the accessory arteries as vessels entering the kidney from the hilum along with the main renal artery, whereas the aberrant arteries enter the kidney directly from the capsule outside the hilum. These accessory/aberrant renal arteries usually originate from the abdominal aorta or iliac arteries; however, they can, on rare occasion, arise from the lower thoracic aorta or from the lumbar or mesenteric arteries.

Finally, in 2010 Daescu et al. [14] imposed a new classification: the renal arteries can be hilar and polar (superior/ inferior). The polar arteries were divided into four groups: (1) solitary, (2) pedicular, if the second one is accompanied by a polar vein and a nerve plexus, (3) false supernumerary, if it replaces the segmental artery and (4) true supernumerary artery, if the respective segmental artery emerges from the renal artery.

The relevance scores for nomenclature variants based on the numbers of articles published on PubMed, which contains the most popular terms used for naming renal arteries, are given in Table I.

It is also worth mentioning that the occurrence of accessory renal arteries differs according to side of the body and the part of the kidney where the supernumerary vessel enters its parenchyma. This information is included in Table II [10].

\section{Embryogenesis of renal vessels}

The multiple renal artery (MRA) is a vestigial structure caused by failure to degenerate during the ascent of metanephros. The development of the kidney and its vessels is complex, and the development of kidney arterioles is poorly understood [15]. In an $18 \mathrm{~mm}$ fetus, the developing mesonephros, metanephros, suprarenal glands, and gonads are supplied by nine pairs of lateral mesonephric arteries arising from the dorsal aorta [16]. Felix divides these nine pairs of arteries into three groups: cranial ( $1^{\text {st }}$ and $2^{\text {nd }}$ pair), middle ( $3^{\text {rd }}-5^{\text {th }}$ pair) and caudal ( $6^{\text {th }}-9^{\text {th }}$ pair) [16]. The renal arteries develop from a single pair from the middle group. The remaining arteries of the middle group give rise to the accessory or the aberrant renal arteries [17]. Renal vascular segmentation was originally recognized by Hunter in 1974 [18]. Further 
Table I. Relevance of different nomenclature of renal arteries when more than one renal artery is present

\begin{tabular}{|lcc|}
\hline Variable & Artery & Arteries \\
\hline Accessory & $486 / 6103=\sim 7.96 \%$ & $439 / 4048=\sim 10.84 \%$ \\
\hline Multiple & $3130 / 6103=\sim 51.29 \%$ & $2036 / 4048=\sim 50.3 \%$ \\
\hline Supernumerary & $60 / 6103=\sim 0.98 \%$ & $57 / 4048=\sim 1.41 \%$ \\
\hline Aberrant & $192 / 6103=\sim 3.15 \%$ & $152 / 4048=\sim 3.75 \%$ \\
\hline Supplementary & $37 / 6103=\sim 0.61 \%$ & $25 / 4048=\sim 0.62 \%$ \\
\hline Hilar & $223 / 6103=\sim 3.65 \%$ & $158 / 4048=\sim 3.9 \%$ \\
\hline Additional & $1744 / 6103=\sim 28.57 \%$ & $1001 / 4048=\sim 24.73 \%$ \\
\hline Perforated & $28 / 6103=\sim 0.46 \%$ & $19 / 4048=\sim 0.47 \%$ \\
\hline Polar & $203 / 6103=\sim 3.33 \%$ & $161 / 4048=\sim 3.98 \%$ \\
\hline Total & 6103 & 4048 \\
\hline
\end{tabular}

Table II. Differences in frequency of presence of accessory renal arteries due to side of the body and area of kidney in which supernumerary vessels enter its parenchyma

\begin{tabular}{|lcc|}
\hline Arterial feature & Right kidney & Left kidney \\
\hline Two hilar arteries & $37.5 \%$ & $53.6 \%$ \\
\hline Three hilar arteries & $23.2 \%$ & $14.5 \%$ \\
\hline Four hilar arteries & $1.79 \%$ & $4.4 \%$ \\
\hline One superior polar & $7.14 \%$ & $11.6 \%$ \\
\hline One inferior polar & $3.57 \%$ & $2.9 \%$ \\
\hline Extra-hilar superior polar & $28.6 \%$ & $11.6 \%$ \\
\hline Extra-hilar inferior polar & $0 \%$ & $1.4 \%$ \\
\hline
\end{tabular}

studies revealed that on the basis of vascular supply, the renal parenchyma is divided into five segments: apical, upper, middle, lower and posterior. The main renal artery separates initially into anterior and posterior branches. The anterior branch almost always supplies the upper, middle and lower segments of the kidney. The posterior branch nourishes the posterior and lower segments. The lower renal segment is often fed by an accessory vessel [19].

According to Zahoi [20], kidneys with one renal artery can be classified morphologically on the basis of segmentation type. The renal parenchyma was divided into 5 segments in $57 \%$ of studied cases, into 6 segments in $31.64 \%$, into 7 segments in $5.7 \%$, into 4 segments in $3.8 \%$ and finally, into 8 segments in $1.9 \%$ of cases. When accessory renal arteries were present, 24 morphological types were described. In $57.14 \%$ of studied cases, 5 renal segments were present, 6 renal segments in 33.33\%, 7 segments in $7.14 \%$ and 8 renal segments in $2.38 \%$. On the basis of renal corrosion casts of kidneys with 2 renal arteries (88\%) and 3 renal arteries
(12\%), Matusz et al. [21] found the renal parenchyma to be divided into 5 segments in $68 \%$ of cases, into 6 segments in $25.33 \%$, into 7 segments in $4 \%$ and 8 renal segments in $2.67 \%$ of cases.

A study performed in 2014 showed that within the embryonic kidney, several putative progenitors marked by the expression of either winged-forkhead transcription factor 1 (Foxd1+ progenitor), aspartyl-protease renin (Ren+ progenitor), and/or hemangioblasts ( $\mathrm{SCl}+$ progenitor) are likely to differentiate and endow most of the cells of the renal arterial tree [15]. While such surveys may better clarify the trigger in the process of developing MRAs, it is currently only possible to explain how this course takes place, but the factor or factors which directly initiate it remain unknown.

\section{Morphological and demographic aspects}

The frequency of occurrence of MRA varies in a wide range of studies. On average, the MRA has been observed in about $30 \%$ of normal subjects [22-24]. However, the frequency of presence of MRA varies widely with ethnicity (Table III) $[2,10,12,13,24-73]$. Therefore, knowledge of anatomic variants in each population is valuable. The incidence of MRA varies widely with ethnicity, ranging from $4 \%$ in Malaysians [58] to $61.5 \%$ in Indians $[32,34]$. The frequency of supernumerary renal arteries was found to be $39.2 \%$ in a North Indian population. It tends to be more common in Africans (37\%) and Caucasians (35\%), and less common in Indian citizens $(17 \%)[64,74]$. In a Chinese population frequency of occurrence of accessory renal arteries was found to be $14.5 \%$ [35] In a Caribbean population, accessory renal arteries were present in $36.1 \%$ of patients [34]. In a Greek population, supernumerary renal arteries occurred in $11.2 \%$ of subjects [41]. Nearly a third of the Colombian population presents one additional renal artery 
Table III. Frequency of multiple renal arteries in different populations

\begin{tabular}{|c|c|c|c|}
\hline Population & Researcher & MRA \% & $\mathrm{N} /($ Total) \\
\hline \multirow[t]{2}{*}{ American } & Lloyd (1935) [25] & 24.2 & $73 / 306$ \\
\hline & Satyapal et al. (2001) [2] & 27.7 & $122 / 440$ \\
\hline Austrian & Janschek et al. (2004) [26] & 19.8 & $47 / 238$ \\
\hline \multirow[t]{2}{*}{ Bosnian } & Talović et al. (2004) [27] & 25.8 & $55 / 213$ \\
\hline & Talović et al. (2013) [23] & 46.2 & $18 / 39$ \\
\hline \multirow[t]{6}{*}{ Brazilian } & Santos Soares et al. (2013) [28] & 12 & $6 / 50$ \\
\hline & Costa et al. (2011) [29] & 18.5 & $47 / 254$ \\
\hline & Aragão et al. (2012) [30] & 21.7 & $13 / 60$ \\
\hline & Tyson et al. (2011) [31] & 23 & $(510)$ \\
\hline & Sampaio and Passos (1992) [10] & 30.4 & $81 / 266$ \\
\hline & Palmieri et al. (2011) [32] & 61.5 & $123 / 200$ \\
\hline Canadian & Kapoor et al. (2011) [33] & 12 & $21 / 171$ \\
\hline Caribbean & Johnson et al. (2013) [34] & 36.1 & $107 / 302$ \\
\hline Chinese & Tao et al. (2013) [35] & 14.5 & $55 / 378$ \\
\hline Colombian & Saldarriaga et al. (2008) [36] & 25 & $97 / 390$ \\
\hline Dutch & Kok et al. (2008) [37] & 21 & $60 / 288$ \\
\hline Egyptian & Harraz et al. (2013) [38] & 14.5 & $108 / 731$ \\
\hline \multirow[t]{2}{*}{ French } & Gerard (1911) [39] & 22 & $63 / 287$ \\
\hline & Laouad et al. (2012) [40] & 27.02 & $70 / 259$ \\
\hline \multirow[t]{3}{*}{ Greek } & Natsis et al. (2014) [41] & 11.2 & $23 / 206$ \\
\hline & Giavroglou (1982) [42] & 17.6 & $327 / 1855$ \\
\hline & Papaloucas et al. (2007) [43] & 27.4 & $59 / 215$ \\
\hline \multirow[t]{4}{*}{ Indian } & Aristotle et al. (2013) [44] & 13.3 & $4 / 30$ \\
\hline & Budhiraja et al. (2010) [45] & 15 & $15 / 100$ \\
\hline & Gupta et al. (2011) [46] & 28.3 & $17 / 60$ \\
\hline & Budhiraja et al. (2013) [47] & 59.5 & $44 / 74$ \\
\hline \multirow[t]{3}{*}{ Iranian } & Amirzargar et al. (2013) [48] & 15.1 & $76 / 502$ \\
\hline & Tarzamni et al. (2008) [49] & 24.8 & $58 / 234$ \\
\hline & Shoja et al. (2008) [50] & 43.2 & $35 / 81$ \\
\hline Italian & Levi (1909) [51] & 25.5 & $49 / 1921$ \\
\hline \multirow[t]{3}{*}{ Japanese } & Kadotani et al. $(2005 ; 2005)[52,53]$ & 14.1 & $48 / 340$ \\
\hline & Adachi (1928) [54] & 22.8 & $77 / 338$ \\
\hline & lijima (1925) [55] & 25 & $15 / 60$ \\
\hline \multirow[t]{2}{*}{ Kenyan } & Sungura (2012) [56] & 11.3 & $23 / 204$ \\
\hline & Ogeng'o et al. (2010) [57] & 14.3 & $51 / 356$ \\
\hline Korean & Choi et al. (1997) [58] & 13 & $65 / 500$ \\
\hline
\end{tabular}


Table III. Cont.

\begin{tabular}{|c|c|c|c|}
\hline Population & Researcher & MRA \% & $\mathrm{N} /($ Total) \\
\hline Malaysian & Hlaing et al. (2012) [59] & 4 & $2 / 50$ \\
\hline New Zealanders & Holden et al. (2005) [13] & 26 & $52 / 200$ \\
\hline \multirow[t]{2}{*}{ Polish } & Wozniak (2000) [60] & 11.2 & $17 / 152$ \\
\hline & Goscicka (1996) [61] & 12.1 & $34 / 280$ \\
\hline Romanian & Bordei et al. (2004) [12] & 20.9 & $57 / 272$ \\
\hline Russian & Seldowitsch (1909) [62] & 17.7 & $53 / 300$ \\
\hline Taiwanese & Hung et al. (2012) [63] & 17 & $17 / 100$ \\
\hline Thai & Khamanarong et al. (2004) [64] & 18.4 & $98 / 534$ \\
\hline Tunisian & Chabchoub et al. (2011) [65] & 21.2 & $44 / 208$ \\
\hline \multirow[t]{7}{*}{ Turkish } & Sezer et al. (2012) [66] & 14.1 & $35 / 249$ \\
\hline & Ozkan et al. (2006) [67] & 14.5 & $248 / 1710$ \\
\hline & Gürkan et al. (2004) [68] & 14.8 & $17 / 115$ \\
\hline & Bakirtas et al. (2006) [69] & 15 & $28 / 187$ \\
\hline & Ciçekcibaşi et al. (2005) [70] & 25 & $45 / 180$ \\
\hline & Gümüş et al. (2012) [71] & 27 & $443 / 1640$ \\
\hline & Zağyapan et al. (2009) [72] & 42 & $63 / 150$ \\
\hline Ukrainian & Vlihova et al. (2001) [73] & 31.8 & $21 / 66$ \\
\hline
\end{tabular}

MRA - multiple renal arteries, $N$ - number of cases where MRA were present, Total - all cases included in study.

and about $3 \%$ of the same population presents two additional renal arteries, most of them reaching the kidney through its hilar region [36]. In a Turkish population, accessory renal arteries were found in $42 \%$ of subjects [72].

However, in our opinion, detection of the MRA may also depend on the sensitivity of diagnostic procedures, for example, cadaveric or radiological examination. A few other methods can be used to reveal the presence of supernumerary renal arteries. These include dissection of cadavers, angiography and magnetic resonance angiography. While many studies are based on dissected cadavers or specimens from an autopsy, other angiographic studies use live patients. It is argued that cadaver dissection probably affords a more accurate determination of the number of renal arteries than aortography [7]. In angiographic studies, MRA were detected less frequently due to their thickness (diameter $<2 \mathrm{~mm}$ ). The MRA are often not detectable when originating from the abdominal aorta, and the arteries entering the kidney outside the hilum are frequently confused with the adrenal or capsular arteries $[67,75]$. It is noteworthy that magnetic resonance angiography failed to predict the anatomy of renal arteries in $10 \%$ of patients with MRA compared to angiography, in which the relative incidence was 3\% [37].
Volume rendering (VR), maximum intensity projection (MIP), and multiplanar reformatted reconstruction (MPR) images may accurately demonstrate accessory renal arteries [76].

The arterial phase of three-dimensional CT angiography is used to depict the renal arteries and is the most sensitive phase for detection of MRA and other possible arterial abnormalities [77]. 3D CTA correctly defines renal arterial anatomy (caliber, number, arterial branching pattern and accessory renal arteries) in $97.6 \%$ of patients and provides better detail of the venous anatomy compared with routine angiography [78]. Rubin et al. [78] showed 3D CT angiography to be $100 \%$ sensitive in the visualization of accessory renal arteries.

Since the average renal diameter is approximately 4-5 $\mathrm{mm}$ and accessory arteries are considered to be smaller, up to $15 \%$ of vessels can be missed by 1-4 detector row CTA [79].

The most common origin of MRA was the abdominal aorta (Figures 1-4). They may be observed unilaterally (Figure 2) and ipsilaterally (Figure 3). Multiple renal arteries rarely originate from the external iliac, lumbar, spermatic, ovarian, inferior mesenteric, superior suprarenal, inferior phrenic, right colic, subcostal, contralateral renal, splenic or thoracic aorta [80] (Figure 5). The most 


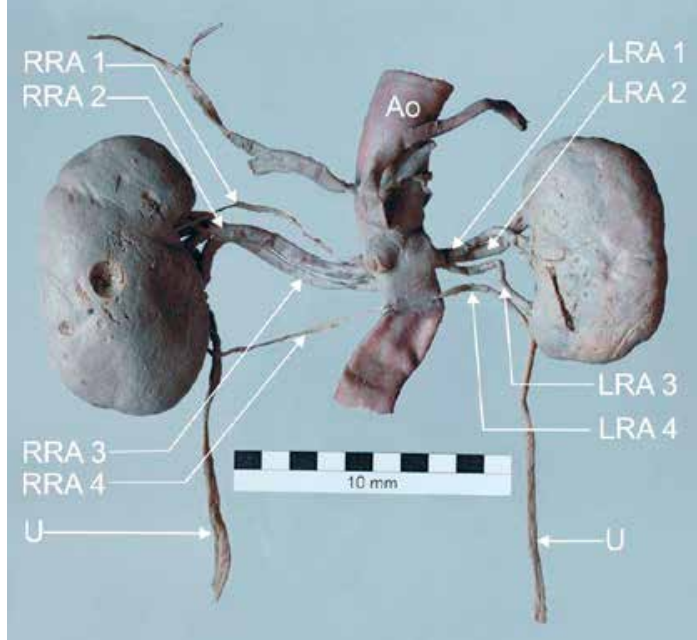

Figure 1. Structures of the retroperitoneal region

Ao - abdominal aorta, RRA 1 - right additional superior hilar renal artery, RRA 2 - main right renal artery, RRA 3 - right additional inferior hilar renal artery, RRA 4 right additional inferior polar renal artery, LRA 1 - left additional superior hilar renal artery, LRA 2 - main left renal artery, LRA 3 - left additional inferior polar renal artery, LRA 4 - left additional inferior polar renal artery, $U$ - urether.

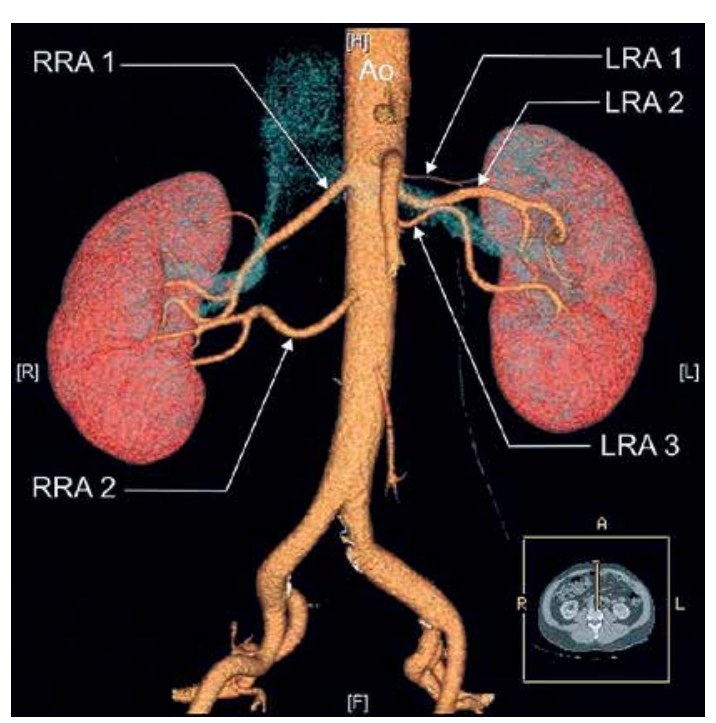

Figure 3. Three-dimensional computed tomography reconstruction of the arteries

Ao - abdominal aorta, RRA 1 - right additional superior hilar renal artery, RRA 2 - main right renal artery, $L R A 1$ - left additional superior polar renal artery, LRA 2-main left renal artery, LRA 3-left additional inferior hilar renal artery.

common type of MRA was accessory renal inferior polar arteries [81], as confirmed by Bordei et al. [12] and our own previous anatomical (Figure 1) and radiological observations (Figure 4). Bordei et al. [12] note that the additional renal arteries mainly entered the kidney through the hilum, together with the main renal artery in $61.11 \%$ of the cases, the superior pole in $9.26 \%$, and the inferior pole in $29.63 \%$.

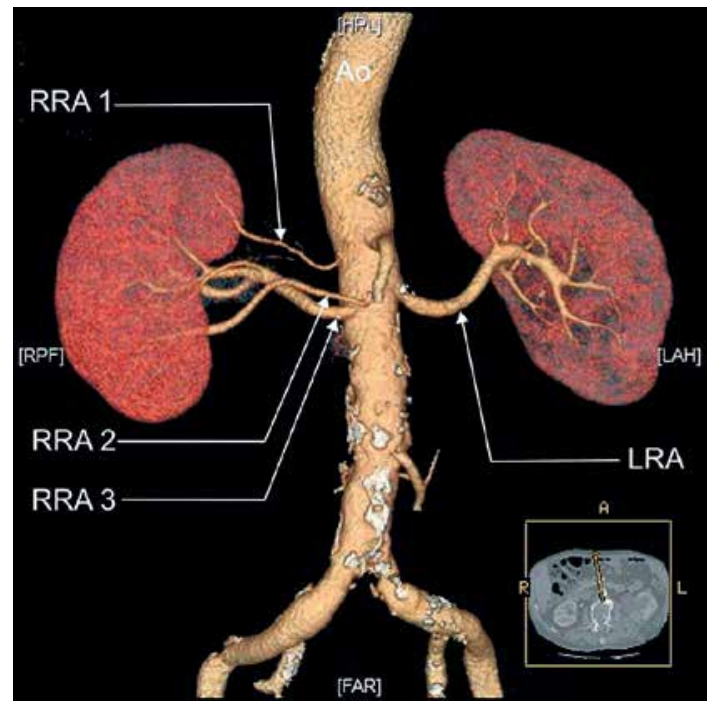

Figure 2. Three-dimensional computed tomography reconstruction of the arteries

Ao-abdominal aorta, $L R A$ - main left renal artery, RRA 1 - right additional superior polar renal artery, RRA 2 right additional superior hilar renal artery, RRA 3 - main right renal artery.

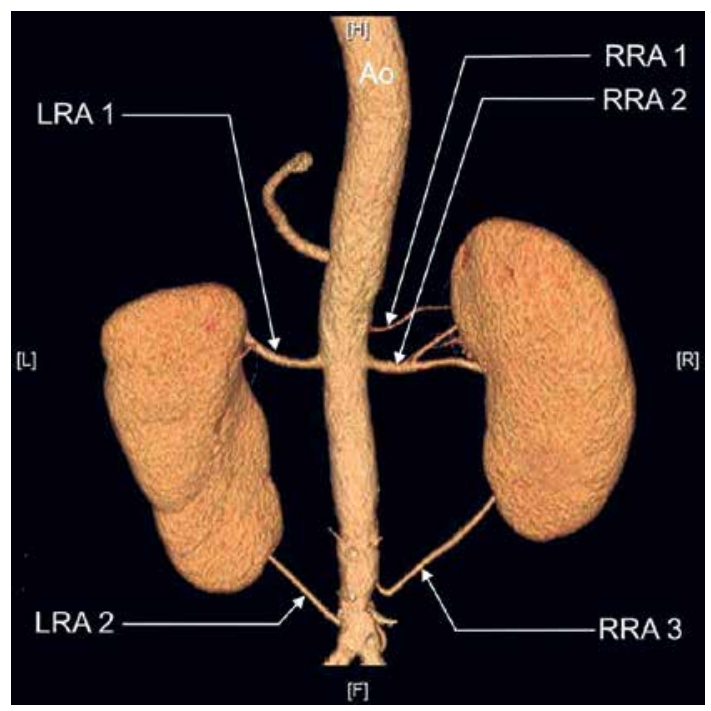

Figure 4. Posterior view of the kidneys and $a b-$ dominal arteries on MDCT angiographies with 3D reconstruction

Ao - abdominal aorta, LRA 1 - main left renal artery, LRA 2 - left additional inferior polar renal artery, RRA 1 right additional superior hilar renal artery, RRA 2 - main right renal artery, RRA 3 - right additional inferior hilar renal artery.

Natsis et al. [41] reported no statistically significant relationship $(p>0.05)$ between gender and the side on which the supernumerary renal artery was situated. However, several authors have observed a higher incidence in males than females $[3,61,64,82,83]$, whereas others conclude the opposite [56, 66, 84, 85] (Table IV).

A review of studies reveals a great difference in the description of MRA incidence depending on 


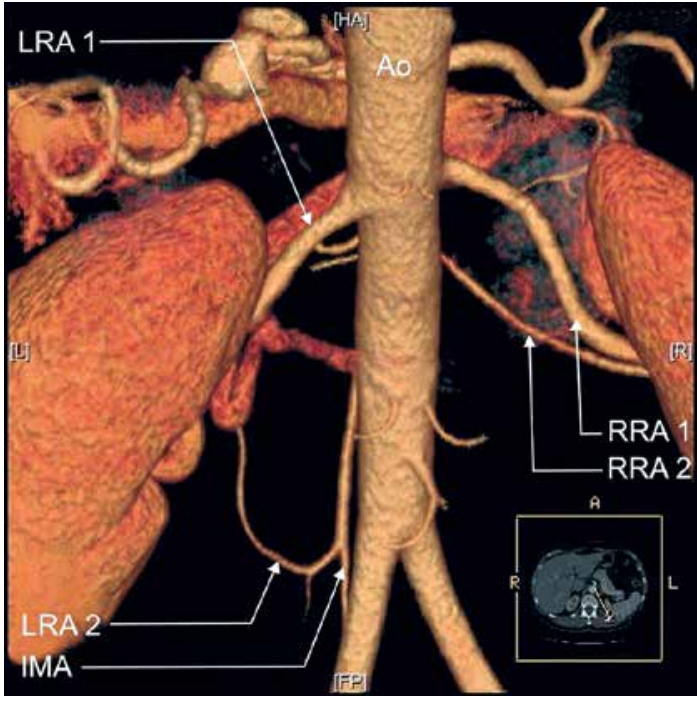

Figure 5. Three-dimensional computed tomography reconstruction of the arteries

Ao - abdominal aorta, IMA - inferior mesenteric artery, LRA 1 - main left renal artery, LRA 2 - left additional inferior hilar renal artery, RRA 1 - main right renal artery, $R R A 2$ - right additional inferior hilar renal artery.

side of occurrence of MRA. Some studies report that MRA are most frequently left-sided [12, 29, $32,34,36,67,72,86-93]$, while others find that the right side predominates $[13,37,49,61,64$, 67, 71, 94-96] (Tables II, IV). More frequent occurrence on the left side of the body and in males is also characteristic for an ectopic kidney. Ectopic kidneys are rare $(0.1 \%)$, and the incidence of pelvic ectopy ranges from approximately 1 in 2200 to 1 in 3000 [97]. An ectopic kidney may present with pain, hydronephrosis, pyelonephritis, fistulae between the gut and the kidney, renal calculi or obstetric problems in females [17].

Adachi studied a series of 1838 kidneys and found additional renal arteries to be present in $23.1 \%$ of cases. He also noted that the number of additional renal arteries ranged from 1 to 4 with a prevalence of $19.81 \%, 2.88 \%, 0.44 \%$, and $0.05 \%$, respectively [98]. In a later study conducted in 2011 by Matusz et al. [98] the number of additional renal arteries found ranged from 1 to 6 with a prevalence of $9 \%$ for one artery, $7 \%$ for two, $1.6 \%$ for three, $0.3 \%$ for four, $0.2 \%$ for five, and $0.1 \%$ for six.

\section{Clinical implications of presence of multiple renal arteries}

Multiple renal arteries have major clinical importance, because overlooking them during pre-operative preparations of patients for surgical procedures may have fatal consequences, especially if laparoscopic methods are used for the procedure. The increasing number of kidney transplants has led to an increase in use of laparoscopic surgical techniques, which, with all their advantages, also have failings. Using these methods reduces the operative field, whereby the risk is increased that variations in vascularization of the kidney may lead to a fatal outcome [99]. Here, it must be emphasized that the effects of the presence of MRA are still to be explored and classified, because accessory vessels are mainly found accidentally during pre-operative procedures or during the diagnostic process. In surgical terms, the upper pole artery represents a major risk, because it is frequently located high up the kidney, meaning that in most cases the surgeons may mistake it for surrounding connective tissue and unknowingly cut through it, thereby causing massive bleeding, which most often leads to a fatal outcome [5]. Furthermore, Rizzari et al. [100] note that individuals with kidneys with 2 or more arteries appear to have an increased incidence of hypertension.

However, in a study which took place from 1996 to 2002 on 185 hypertensive patients who underwent MR angiography of the renal arteries, Gupta and Tello [101] found no statistically significant

Table IV. Frequency of multiple renal arteries according to gender and side

\begin{tabular}{|lccccc|}
\hline Author(s) & Population & \multicolumn{2}{c}{ Gender } & \multicolumn{2}{c|}{ Side } \\
\cline { 3 - 6 } & & $\mathrm{F}(\%)$ & $\mathrm{M}(\%)$ & L (\%) & R (\%) \\
\hline Adachi (1928) [54] & Japanese & 19 & 24 & - & - \\
\hline Aragão et al. (2012) [30] & Brazilian & 7.2 & 6.25 & 10 & 11.7 \\
\hline Ciçekcibaşi et al. (2005) [70] & Turkish & 13.3 & 28.8 & 17.6 & 32.1 \\
\hline Goscicka et al. (1996) [61] & Polish & 12.8 & 9.3 & 7.7 & 11.5 \\
\hline Palmieri et al. (2011) [32] & Brazilian & 58 & 65 & 67 & 56 \\
\hline Saldarriaga et al. (2008) [36] & Colombian & 15.4 & 26.3 & 27.3 & 22.2 \\
\hline Satyapal et al. (2001) [2] & American & 20.2 & 33.1 & 32 & 23.3 \\
\hline Vilhova et al. (2001) [73] & Ukrainian & 33.3 & 30.6 & 35.3 & 28.1 \\
\hline
\end{tabular}

F-female, $M$ - male, $L$ - left, $R$-right. 
difference in the prevalence of renal artery stenosis between patients with MRA and those without MRA. Assuming that the presence of two separate causes of hypertension in the same patient would be unlikely, this finding implies that MRA are a vascular anomaly and not a direct cause of hypertension. Of 185 hypertensive patients, 45 (24\%) showed accessory renal arteries. Of these 45 patients, 9 (20\%) showed renal artery stenosis and 36 (80\%) showed no significant stenosis. Of the 140 patients with a single renal artery, 42 (30\%) showed renal artery stenosis and 98 (70\%) showed no stenosis.

The awareness of the existence of a MRA is very important, as it might complicate reconstructive surgery of abdominal aortic aneurysms and uroradiological procedures [7, 102]. Also hemorrhagic complications, renal artery thrombosis, and warm ischemia time are significantly higher in patients with MRA [23]. For renal transplants, kidneys with accessory renal arteries had a longer mean warm ischaemia time (35.3 vs. $29.2 \mathrm{~min}, p=0.0003$ ) and more urethral complications (6/36 vs. $10 / 312, p=$ 0.0013) [103].

Opinions are divided as to whether the presence of an accessory renal artery is associated with undesirable consequences of kidney transplants. Some studies consider the presence of accessory renal arteries as a contraindication to their use in transplant surgery: since these are end-arteries, the end-arteries must be re-implanted, and this would require several anastomoses and a prolonged ischemic time, leading to a theoretically higher incidence of renal failure, graft rejection and reduced graft function [104]. On the other hand, a study from the National Institute of Kidney Diseases in Lahore, Pakistan reported no association between multiplicities of renal arteries and the risk of vascular complications. They concluded that kidney transplantation using grafts with MRA is as safe as using grafts with a single renal artery, regarding vascular and urological complications and patients and graft survival [23]. Several other studies also confirm this thesis [105-109].

In 2001 Mizoguchi et al. [110] reported an association between anomalies in renal vascularisation and galactosemia, so any patient with galactosemia should be carefully investigated for the presence of any renal vascular anomalies. Bergman et al. [111] found inferior renal polar arteries to be implicated as an etiologic factor in a form of hydronephrosis correctable by surgery.

In 2013, the technique of using epigastric arteries in renal transplantation was re-described [48]. This technique was in use already in 2001 [112]. Anastomosing lower polar arteries to the inferior epigastric artery and upper polar arteries to the superior epigastric artery provides back- flow from accessory renal arteries, which help to prevent thrombosis. Moreover, when using this technique, both ischemic and operating times are reduced. By this technique, the ischemic time and the operating time are reduced. Both in live and cadaver donor kidneys, the lower polar arteries were anastomosed to the inferior epigastric artery and upper polar arteries were anastomosed to the superior epigastric arteries. An injection of papaverine and ablation of the sympathetic nerves of these arteries dilate them and prevent post-operative spasm. In conclusion, this technique can be safely and successfully used for renal transplantation with kidneys possessing MRA, and may be associated with a lower complication rate and better graft function than existing techniques [48].

The diseases related to the renal accessory artery include:

(1) hypertension: the tenuous and tortuous shape of an accessory renal artery usually results in ischemia in the related area. The local blood flow reduction in the kidney stimulates the macula densa cells and juxtaglomerular cells to increase the synthesis and release of renin, and the subsequent renal vascular [2]. Also Mendelsohn [113] claims that patients with accessory renal arteries constitute $27 \%$ of patients with resistant hypertension, and reinforces the importance of denervation of $M R A$, if present, as a treatment for persistent hypertension. Even though the fall in systemic blood pressure will be smaller than in patients with only the main renal artery, the reduction is still noteworthy: he reports a drop of systemic blood pressure in patients with MRA of $21 \mathrm{~mm} \mathrm{Hg}$ in 6 months.

(2) bleeding: non-traumatic renal bleeding is very rare. As an accessory renal artery is tenuous, the diagnosis and localization of the hemorrhage are difficult. New techniques, such as multidetector CT angiography (MDCTA), which can clearly show the accessory renal arteries, provide better approaches for the accessory renal artery disease [24].

(3) hydronephrosis: an accessory renal artery going to the lower pole of the kidney in front of the ureter may compress the ureter and cause hydronephrosis [9, 24].

It is speculated that accessory renal arteries may provide nourishment to renal cell carcinoma. In a CT angiography investigation of 107 patients with renal cell carcinoma, Guan et al. [81] found MRA in 11 (10.3\%) cases and MRA acting as feeding arteries for the renal cell carcinoma in 5 (4.7\%). Catalano et al. [114] report that atypical variants of renal vascularization were found in 5 of 42 patients with renal cell carcinoma: 1 patient with triple renal artery and four with double renal arteries, one of whom also presented with 

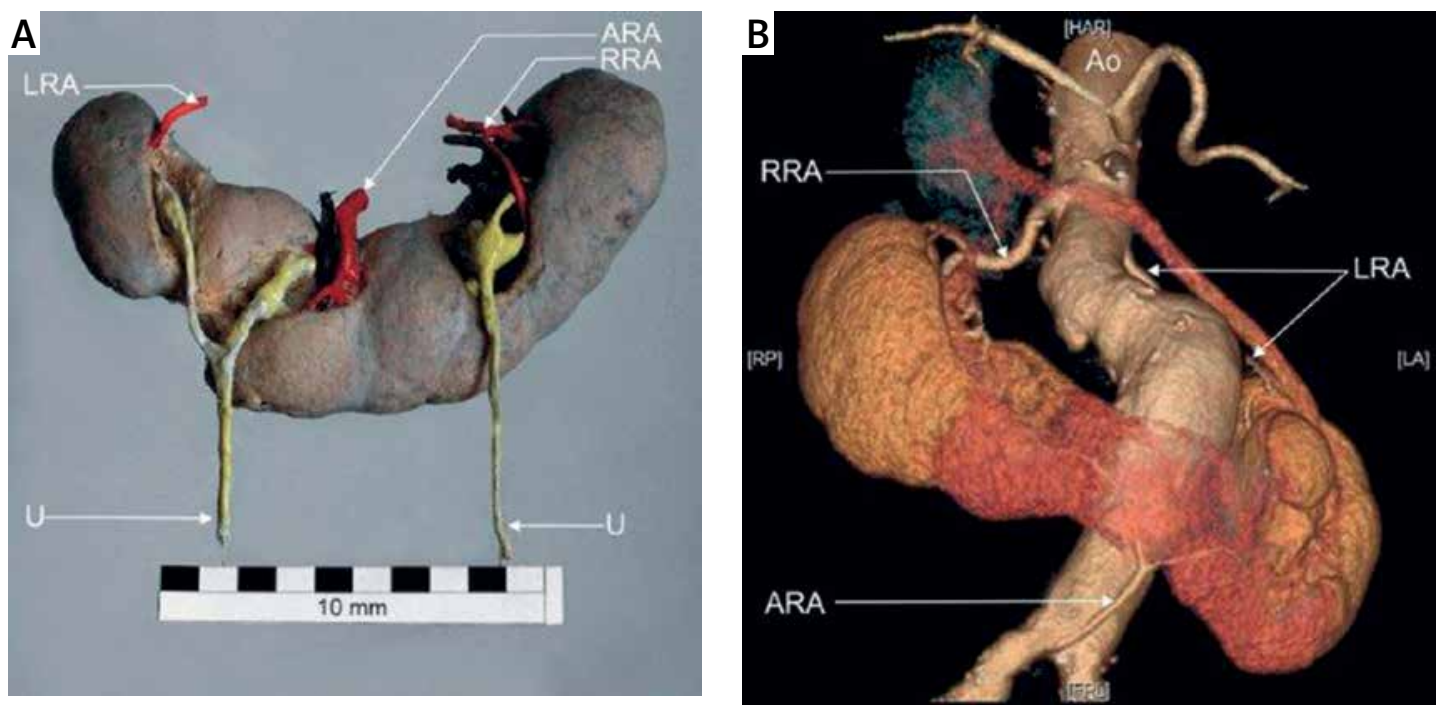

Figure 6. Horseshoe kidney with abdominal arteries: A - anatomical dissection (posterior view), B - volume rendering technique (VRT) image (anterior view from MDCT angiographies with 3D reconstruction)

Ao-abdominal aorta, ARA - additional renal artery (passing to the isthmus), $L R A$ - main left renal artery, RRA - main right renal artery, $\mathrm{U}$-ureter.

a double renal vein [107]. Moreover, awareness of the presence of accessory renal arteries is also important for the procedures prior to laparoscopic nephrectomy in renal cell carcinoma, which is one of the fundamental methods of cancer treatment; this surgical intervention under such circumstances should be more carefully planned to reduce serious potential surgical complications [81]. Undeniably, knowledge of anatomic variants is of great importance for all procedures in the abdominal region [115].

\section{Coexistence of other atypical variants of vascularization}

The occurrence of MRA may also be associated with coexistence of other atypical variants of vascularization, especially connected with the genito-urinary system. For example, MRA can be accompanied by double testicular arteries [116] Moreover, the presence of accessory renal arteries can also be associated with dislocation of the kidney and its hilum: an ectopic kidney [17]. Yakeishi et al. [117] described a case of horseshoe kidney with four surplus renal arteries: one branching from the main renal artery and three following from the abdominal aorta. Furthermore, an accessory renal artery can have a common origin with the inferior mesenteric artery [118]. Based on our experience in the field of anatomical dissection (Figure 6 A) and radiological investigation (Figure 6 B), the horseshoe kidney usually has three renal arteries: two main (left and right renal artery) and one additional, which passes to the isthmus (Figure 6).

\section{Conclusions}

The origin, number and topography of accessory (multiple) renal arteries are complex are associated with renal embryogenesis. Knowledge of the variations of the renal arteries has grown in importance with the increasing number of renal transplants, vascular reconstructions and various surgical, urological and radiological techniques performed in recent years. Accessory renal arteries may coexist with other atypical vascularization variants, especially in the genito-urinary system - the testicular arteries, for example. The potential implications of the coexistence of accessory renal arteries and other atypical vascularization and finding the direct factor leading to these anatomical variants require further study.

\section{Acknowledgments}

The authors thank the donors and families of the cadavers used for this study.

\section{Conflict of interest}

The authors declare no conflict of interest.

\section{References}

1. Mir NS, ul Ashfag H, Ryiaz R, et al. Bilateral duplication of renal vessels: anatomical, medical and surgical perspective. Int J Health Sci (Qassim) 2008; 2: 179-85.

2. Satyapal KS, Haffejee AA, Singh B, Ramsaroop L, Robbs JV, Kalideen JM. Additional renal arteries: incidence and morphometry. Surg Radiol Anat 2001; 23: 33-8.

3. Singh D, Finelli A, Rubinstein M, Desai MM, Kaouk J, Gill IS. Laparoscopic partial nephrectomy in the presence of multiple renal arteries. Urology 2007; 69: 444-7. 
4. Eustachi Opuscula anatomia, Venice 1564.

5. Merklin RJ, Michels NA. The variant renal and suprarenal blood supply with data on the inferior phrenic, ureteral and gonadal arteries: a statistical analysis based on 185 dissections and reviews of the literature. J Int Coll Surg 1958; 29: 41-76.

6. Graves FT. The aberrant renal artery. J Anat 1956; 90: 553-8.

7. Geyer JR, Poutasse EF. Incidence of multiple renal arteries on aortography. Report of a series of 400 patients, 381 of whom had arterial hypertension. JAMA 1962; 182: 120-5.

8. Poisel S, Spängler HP. On aberrant and accessory renal arteries in kidneys of typical position. Anat Anz 1969; 124: 244-59.

9. Stephens FD. Uterovascular hydronephrosis and the "aberrant" renal vessels. J Urol 1982; 128: 984-7.

10. Sampaio FJ, Passos MA. Renal arteries: anatomic study for surgical and radiological practice. Surg Radiol Anat 1992; 14: 113-7.

11. Vilhova I, Kryvko YY, Maciejewski R. The radioanatomical research of plural renal arteries. Folia Morphol (Warsz) 2001; 60: 337-41.

12. Bordei P, Sapte E, lliescu D. Double renal arteries originating from the aorta. Surg Radiol Anat 2004; 26: 474-9.

13. Holden A, Smith A, Dukes P, Pilmore H, Yasutomi M. Assessment of 100 live potential renal donors for laparoscopic nephrectomy with multi-detector row helical CT. Radiology 2005; 237: 973-80.

14. Daescu E, Jianu AM, Motoc A, Niculescu MC, Rusu MC. The renal polar arteries - anatomical considerations. Med Evolut 2010; 16: 11-5.

15. Sequeira-Lopez ML, Lin EE, Li M, Hu Y, Sigmund CD, Gomez RA. The earliest metanephric arteriolar progenitors and their role in kidney vascular development. Am J Physiol Regul Integr Comp Physiol 2014; 308: R138-49.

16. Felix W. Mesonephric arteries (aa. mesonephrica). In: Manual of human embryology, Keibel F, Mall FP (eds). Lippincott, Philadelphia, Pa, USA 1912; 22: 820-5.

17. Krishnaveni C, Kulkarni R. A right ectopic kidney with bilateral multiple anomalie of the renal vasculature a case report. J Clin Diagn Res 2013; 7: 150-3.

18. Hunter J. Vasculature of the body. Br J Surg 1794; 38: 1-8.

19. Rattaiah K, Venkateswara Rao P. A study of renal anomalies: aberrant vessel. J Evid Med Healthcare 2015; 2: 1302-11.

20. Zahoi DE. Arterial segmentation of renal parenchyma with single and multiple renal arteries. A comparative study on corrosion casts. FASEB J 2009; 23: 820-6.

21. Matusz P, Bordei P, Sapte E, Iliescu D, Bulbuc I. Segmentation of renal parenchyma in the case of presence of additional renal arteries. FASEB J 2012; 26: 722-7.

22. Anson BJ, McVay CB. The topographical positions and the mutual relations of the visceral branches of the abdominal aorta. A study of 100 consecutive cadavers. Anat Rec 1936; 67: 7-15.

23. Ashraf HS, Hussain I, Siddiqui AA, Ibrahim MN, Khan MU. The outcome of living related kidney transplantation with multiple renal arteries. Saudi J Kidney Dis Transpl 2013; 24: 615-9.

24. Zhang Q, Ji Y, He T, Wang. Ultrasound-guided percutaneous renal biopsy-induced accessory renal artery bleeding in an amyloidosis patient. Diagn Pathol 2012; 7: 176 .
25. Lloyd LW. The renal artery in whites and American Negroes. Am J Phys Anthropol 2005; 20: 153-63.

26. Janschek EC, Rothe AU, Hölzenbein TJ, et al. Anatomic basis of right renal vein extension for cadaveric kidney transplantation. Urology 2004; 63: 660-4.

27. Talović E, Kulenović A, Voljevica A, Ovcina F, Prevljak S. Angiographic imaging of supernumerary kidney arteries by nonselective angiography. Med Arh 2004; 58: 263-7.

28. Santos Soares TR, Soares Ferraz J, Dartibale CB, Marco Oliveira IR. Variations in human renal arteries. Acta Scient Biol Sci 2013; 35: 277-82.

29. Costa HC, Moreira RJ, Fukunaga P, Fernandes RC, Boni RC, Matos AC. Anatomic variations in vascular and collecting systems of kidneys from deceased donors. Transplant Proc 2011; 43: 61-3.

30. Aragão JA, de Oliveira Pacheco JM, Silva LA, Reis FP. Frequency of multiple renal arteries in human foetuses. Surg Radiol Anat 2012; 34: 133-6.

31. Tyson MD, Castle EP, Ko EY, et al. Living donor kidney transplantation with multiple renal arteries in the laparoscopic era. Urology 2011; 77: 1116-21.

32. Palmieri BJ, Petroianu A, Silva LC, Andrade LM, Alberti LR. Study of arterial pattern of 200 renal pedicle through angiotomography. Rev Col Bras Cir 2011; 38: 116-21.

33. Kapoor A, Lambe S, Kling AL, Piercey KR, Whelan PJ. Outcomes of laparoscopic donor nephrectomy in the presence of multiple renal arteries. Urol Ann 2011; 3: 62-5.

34. Johnson PB, Cawich SO, Shah SD, et al. Accessory renal arteries in a Caribbean population: a computer tomography based study. Springer Plus 2013; 2: 443.

35. Tao XF, Zhu JQ, Wu YW, et al. Dual-energy computed tomography angiography for evaluating the renal vascular variants. Chin Med J (Engl) 2013; 126: 650-4.

36. Saldarriaga B, Pérez AF, Ballesteros LE. A direct anatomical study of additional renal arteries in a Colombian mestizo population. Folia Morphol (Warsz) 2008; 67: 129-34.

37. Kok NF, Dols LF, Hunink MG, et al. Complex vascular anatomy in live kidney donation: imaging and consequences for clinical outcome, Transplantation 2008; 85: $1760-5$.

38. Harraz AM, Shokeir AA, Soliman SA, et al. Fate of accessory renal arteries in grafts with multiple renal arteries during live-donor renal allo-transplantation. Transplant Proc 2013; 45: 1232-6.

39. Gerard G. Les artères rénales (Note statistique d'après l'étude de 150 paires de reins). J Anat Physiol Norm Pathol Homme Animaux 1911; 47: 531.

40. Laouad I, Bretagnol A, Fabre E, et al. Kidney transplant with multiple renal artery grafts from deceased donors: are long-term graft and patient survival compromised? Prog Transplant 2012; 22: 102-9.

41. Natsis K, Paraskevas G, Panagouli E, et al. A morphometric study of multiple renal arteries in Greek population and a systemic review. Rom J Morphol Embryol 2014; 55 (3 Suppl.): 1111-22.

42. Giavroglou K. Angiographic control of renal arteries. PhD Thesis, Thessaloniki, 1982; 50-2.

43. Papaloucas C, Fiska A, Pistevou-Gombaki K, et al. Angiographic evaluation of renal artery variation amongst Greeks. Aristotle Univ Med J 2007; 34: 43-7.

44. Aristotle S, Sundarapandian, Felicia C. Anatomical study of variations in the blood supply of kidneys. J Clin Diagn Res 2013; 7: 1555-7.

45. Budhiraja V, Rastogi R, Asthana AK. Renal artery variations: embryological basis and surgical correlation. Rom J Morphol Embryol 2010; 51: 533-6. 
46. Gupta A, Gupta R, Singhla RK. The accessory renal arteries: a comparative study in vertebrates with its clinical implications. J Clin Diagn Res 2011; 5: 970-3.

47. Budhiraja V, Rastogi R, Anjankar V, Babu CSR, Goel P. Supernumerary renal arteries and their embryological and clinical correlation: a cadaveric study from North India. ISRN Anat 2013; 2013: 405712.

48. Amirzargar MA, Babolhavaeji $\mathrm{H}$, Hosseini SA, et al. The new technique of using the epigastric arteries in renal transplantation with multiple renal arteries. Saudi J Kidney Dis Transpl 2013; 24: 247-53.

49. Tarzamni MK, Nezami N, Rashid RJ, Argani H, Hajealioghli P, Ghorashi S. Anatomical differences in the right and left renal arterial patterns. Folia Morphol (Warsz) 2008; 67: 104-10.

50. Shoja MM, Tubbs RS, Shakeri A, et al. Peri-hilar branching patterns and morphologies of the renal artery: a review and anatomical study. Surg Radiol Anat 2008; 30: 375-82.

51. Levi G. Le variazioni delle arterie surrenali e renali studia te col methodo statistico seriale. Arch Ital Anat Embriol 1909; 8: 35-71.

52. Kadotani Y, Okamoto M, Akioka K, et al. Management and outcome of living kidney grafts with multiple arteries. Surg Today 2005; 35: 459-66.

53. Kadotani Y, Okamoto M, Akioka K, et al. Renovascular reconstruction of grafts with renal artery variations in living kidney transplantation. Transplant Proc 2005; 37: 1049-51.

54. Adachi B. Das Arteriensystem der Japaner II. Verlag der Kaiserlich-Japanischen Universität zu Kyoto, Maruzen Publishing Co. 1928; 74-87.

55. lijima $H$. Lageverhalten der arteria und vena renalis Und des ureters der Japaner. Tokyo-lji-Shinshi 1925; 2415.

56. Sungura RE. The CT angiography pattern of renal arteria anatomy among Africans and its implication on renal transplantation: a cross sectional descriptive study at Kenyatta National Hospital. Dig Repository 2012; 56: 307.

57. Ogeng'o JA, Masaki CO, Sinkeet SR, Muthoka JM, Murunga AK. Variant anatomy of renal arteries in a Kenyan population. Ann Transplant 2010; 15: 40-5.

58. Choi SS, Kim SC, Han DJ. Clinical outcome of microsurgical multiple renal artery reconstruction in renal transplantation. J Korean Soc Transplant 1997; 11: 81-94.

59. Hlaing KP, Das S, Sulaiman IM, et al. Accessory renal vessels at the upper and lower pole of the kidney: a cadaveric study with clinical implications. Bratisl Lek Listy 2012; 111: 308-10.

60. Wozniak WT. Origin of the renal arteries from sides of aorta. Folia Morphol (Warsz) 2000; 58: 259-61.

61. Goscicka D, Szpinda M, Kochan J. Akzessorische Nierenarterien bei menschlichen Feten. Ann Anat 1996; 178: 559-63.

62. Seldowitsch JB. Über die multiplicität der Nierenarterien und deren chirurgische Bedeutung. Arch Klin Chir 1909; 89: 1071-112.

63. Hung CJ, Lin YJ, Chang SS, Chou TC, Lee PC. Kidney grafts with multiple renal arteries is no longer a relative contraindication with advance in surgical techniques of laparoscopic donor nephrectomy. Transplant Proc 2012; 44: 36-8.

64. Khamanarong K, Prachaney P, Utraravichien A, Tong Un T, Sripaoraya K. Anatomy of renal arterial supply. Clin Anat 2004; 17: 334-6.
65. Chabchoub K, Mhiri MN, Bahloul A, et al. Does kidney transplantation with multiple arteries affect graft survival? Transplant Proc 2011; 43: 3423-5.

66. Sezer TO, Solak I, Toz H, Kardaslar B, Er A, Hoscoskun C. Long-term outcomes of kidney transplants with multiple renal arteries: a retrospective study. Transplant Proc 2012; 44: 1697-9.

67. Ozkan U, Oğuzkurt L, Tercan F, Kizilkiliç O, Koç Z, Koca N. Renal artery origins and variations: angiographic evaluation of 855 consecutive patients. Diagn Interv Radiol 2006; 12: 183-6.

68. Gürkan A, Kaçar S, Başak K, Varilsüha C, Karaca C. Do multiple renal arteries restrict laparoscopic donor nephrectomy? Transplant Proc 2004; 36: 105-7.

69. Bakirtas H, Guvence N, Eroglu M, et al. Surgical approach to cases with multiple renal arteries in renal transplantation. Urol Int 2006; 76: 169-72.

70. Ciçekcibaşi AE, Ziylan T, Salbacak A, Seker M, Büyükmumcu M, Tuncer I. An investigation of the origin, location and variations of the renal arteries in human fetuses and their clinical relevance. Ann Anat 2005; 187: 421-7.

71. Gümüş H, Bükte $Y$, Ozdemir E, et al. Variations of renal artery in 820 patients using 64-detector CT-angiography. Ren Fail 2012; 34: 286-90.

72. Zağyapan R, Pelin C, Kürkçüoğlu A. A retrospective study on multiple renal arteries in Turkish population. Anatomy 2009; 3: 35-9.

73. Vilhova I, Kryvko YY, Maciejewski R. The radioanatomical research of plural renal arteries. Folia Morphol (Warsz) 2001; 60: 337-41.

74. Muktyaz H, Mahboobul H, Nema U, Khalid H, Nigar H. Bilateral variation of renal artery and its clinical significance in North Indian population. Innovative Journal of Medical Health and Science 2013; 3: 121-3.

75. Platt JF, Ellis JH, Korobkin M, Reige K. Helical CT evaluation of potential kidney donors: findings in 154 subjects. AJR Am J Roentgenol 1997; 169: 1325-30.

76. Miclaus G, Sas I, Samfa J, et al. Seven renal arteries: a case report using MDCT tomography. Rom J Morphol Embryol 2014; 55 (3 Suppl.): 1181-4.

77. Toprak U, Erdogan A, Gulbay M, Karademir MA, Pasaoglu E, Akar OE. Preoperative evaluation of renal anatomy and renal masses with helical CT, 3D-CT and 3D-CT angiography. Diagn Interv Radiol 2005; 11: 35-40.

78. Rubin GD, Alfrey EJ, Dake MD, et al. Assessment of living renal donors with spiral CT. Radiology 1995; 195: 457-62.

79. Kumamaru K, Hoppel B, Mather R, Rybicki F. CT: current technology and clinical use. Radiol Clin North Am 2010; 48: 213-35.

80. Van Baalen JM, Van Bockel HJ. Thoracic origin of the right renal artery. J Vasc Surg 1994; 19: 762-3.

81. Guan WH, Han Y, Zhang X, Chen DS, Gao ZW, Feng XS. Multiple renal arteries with renal cell carcinoma: preoperative evaluation using computed tomography angiography prior to laparoscopic nephrectomy. J Int Med Res 2013; 41: 1705-15.

82. Mendoza JM, Melcher ML, Daniel B, Tan JC. Multiple renal arteries and non-contrast magnetic resonance angiography in transplant renal artery stenosis. Clin Kidney J 2012; 5: 272-5.

83. Perla SB, Bilateral multiple renal arteries - an anatomical study. Webmed Central Anatomy 2012; 3: WMCD003993.

84. Satyanarayana N, Guha R, Nitin V, Praveen G, Datta AK, Sunitha P. Left inferior accessory renal arteries, its em- 
bryological basis and clinical significance. J Coll Med Sci Nepal 2011; 7: 65-8.

85. Ali Mohammed AM, Elseed Abdalrasol RG, Alamin Abdalhai K, Gommaa Hamad M. Accessory renal vessels. Acta Inform Med 2012; 20: 196-7.

86. Adachi B (ed). Das Arteriensystem der Japaner. Maruzen, Kyoto 1928; 251.

87. Cerny JC, Karsch D. Aberrant renal arteries. Urology 1973; 2: 623-6.

88. Doppman J. An ectopic renal artery. Br J Radiol 1967; 40: 312-3.

89. Gesase AP. Rare origin of supernumerary renal vessels supplying the lower pole off the left kidney. Ann Anat 2007; 189: 53-8.

90. Kocabıyık N, Yalçın B, Kııı̧ C, Kırıcı Y, Ozan H. Accessory renal arteries and an anomalous testicular artery of high origin. Gulhane Med J 2005; 47: 141-3.

91. Kumar A, Gupta RS, Srivastava A, Bansal P. Sequential anastomosis of accessory renal artery to inferior epigastric artery in the management of multiple arteries in live related renal transplantation: a critical appraisal. Clin Transplant 2001; 15: 131-5.

92. Macalister A. Multiple renal arteries. J Anat Physiol 1883; 17: 250-2.

93. Raikos A, Paraskevas GK, Natsis K, Tzikas A, Njau SN. Multiple variations in the branching pattern of the abdominal aorta. Rom J Morphol Embryol 2010; 51: 585-7.

94. Glodny B, Tröbinger MG, Hofmann KJ, Rehder P, Trieb T, Petersen J. A right accessory renal artery arising from a left additional common renal artery stem. Cardiovasc Intervent Radiol 2009; 32: 804-6.

95. Gurses IA, Kale A, Gayretli O, et al. Bilateral variations of renal and testicular arteries. Int J Anat Variat 2009; 2: 45-7.

96. Mamatha H, D'Souza AS. Bilateral accessory renal arteries with a rare origin of the testicular artery: an embryological basis. J Clin Diagn Res 2011; 5: 1267-9.

97. Çilingiroğlu M, Kostas M, Mark W. Successful recanalization of a left common iliac artery chronic total occlusion adjacent to an ectopic renal artery at the aortoiliac bifurcation. Türk Kardiyol Dern Arş - Arch Turk Soc Cardiol 2013; 41: 347-50.

98. Matusz P, Miclaus G, Ples H. Study of the renal additional arteries on 1,000 CT angiography continuous series. Clin Anat 2011; 24: 408.

99. Talović E, Voljevica A. An unusual renal accessory artery originating from the thoracic aorta and its potential clinical implications. Acta Medica Academica 2013; 42: 80-2.

100. Rizzari MD, Suszynski TM, Gillingham KJ, Matas AJ, Ibrahim HN. Outcome of living kidney donors left with multiple renal arteries. Clin Transplant 2012; 26: E7-11.

101. Gupta A, Tello R. Accessory renal arteries are not related to hypertension risk: a review of MR angiography data. AJR Am J Roentgenol 2004; 182: 1521-4.

102. Shakeri AB, Tubbs RS, Shoja MM, et al. Bipolar supernumerary renal artery. Surg Radiol Anat 2007; 29: 89-92.

103. Carter J, Freise C, McTaggart R, et al. Laparoscopic procurement of kidneys with multiple renal arteries is associated with increased ureteral complications in the recipient. Am J Transplant 2005; 5: 1312-8.

104. Sebastia C, Peri L, Salvador R, et al. Multidetector CT of living renal donors: lessons learned from surgeons. Radiographics 2010; 30: 1875-90.

105. Abbaszadeh S, Nourbala MH, Alghasi M, Sharafi M. Does renal artery multiplicity have impact on patient and allograft survival rates? Int J Nephrol Urol 2009; 1: 45-50.

106. Aydin C, Berber I, Altaca G, Yigit B, Titiz I. The outcome of kidney transplants with multiple renal arteries. BMC Surg 2004; 4: 4

107. Eduardo M, Auro A, Souza Willian C. Surgical complications after renal transplantation in grafts with multiple arteries. Int Braz J Urol 2005; 31: 125-30.

108. Jafri SS, Younas M, Chughtai MN. Surgical aspects and outcomes of kidney transplantation with multiple renal arteries. Annals 2009; 15: 88-92.

109. Singh PB, Goyal NK, Kumar A, et al. Renal transplantation using live donors with vascular anomalies: a salvageable surgical challenge. Saudi J Kidney Dis Transpl 2008; 19: 554-8.

110. Mizoguchi N, Sakura N, Ono H, Naito K, Hamakawa M. Congenital porto-left venous shunt as a cause of galactosemia. J Inherit Metab Dis 2001; 24: 72-8.

111. Bergman RA, Afifi AK, Miyauchi R. Inferior renal polar arteries. Illustrated Encyclopedia of Human Anatomic Variation: Opus II: Cardiovascular System: Arteries: Abdomen, Celiac Trunk Arteries. http://www. anatomyatlases.org/AnatomicVariants/Cardiovascular/ Text/Arteries/CeliacTrunk.shtml

112. Kumar A, Gupta RS, Srivastava A, Bansal P. Sequential anastomosis of accessory renal artery to inferior epigastric artery in the management of multiple arteries in live related renal transplantation: a critical appraisal. Clin Transplant 2001; 15: 131-5.

113. Mendelsohn FO. Does complete renal denervation translate into superior clinical outcomes? Lessons learned from denervation of accessory renal arteries. Clin Res Cardiol 2014; 103: 681-3.

114. Catalano C, Fraioli F, Laghi A, et al. High-resolution multidetector CT in the pre-operative evaluation of patients with renal cell carcinoma. Am J Roentgenol 2003; 180: 1271-7.

115. Polguj M, Topol M, Majos A. An unusual case of left venous renal entrapment syndrome - a new type of nutcracker phenomenon? Surg Rad Anat 2013; 35: 263-7.

116. Anjamrooz SH, Taghavi MM, Abedinzadeh M, Yazdi SM, Azari H. Coexistence of multiple arterial variations in the genitourinary system. Ital J Anat Embryol 2013; 118: 128-35.

117. Yakeishi A, Saga T, So H, et al. A case of horseshoe kidney with surplus renal arteries. Kurume Med J 2007; 54: 89-93.

118. Armstrong BG, Hunt TH, Price CW, Resnick MI. Common origin of inferior mesenteric and accessory renal artery. Urology 1979; 14: 298-9. 